\title{
Pencapaian Target Penerimaan Pajak Atas Kegiatan Pemeriksaan (Studi pada Kantor Pelayanan Pajak Madya Malang)
}

\author{
Mohammad Yamin ${ }^{1}$, Erwin Saraswati², Endang Mardiati ${ }^{3}$ \\ 1Pegawai Kantor Pelayanan Pajak Madya Malang \\ 2Jurusan Akuntansi, Fakultas Ekonomi dan Bisnis, Universitas Brawijaya \\ 3Jurusan Akuntansi, Fakultas Ekonomi dan Bisnis, Universitas Brawijaya
}

\begin{abstract}
Abstrak
Penelitian ini bertujuan untuk mengevaluasi penyebab pemeriksa pajak tidak dapat mencapai rencana penerimaan pajak dari kegiatan pemeriksaan serta alternatif solusi yang dapat dilakukan untuk mengoptimalkan penerimaan pajak dari kegiatan pemeriksaan di masa yang akan datang. Penelitian ini merupakan penelitian deskriptif dengan pendekatan kualitatif. Jenis data yang dikumpulkan dalam penelitian ini adalah data dokumentasi dari kegiatan pemeriksaan berupa SP2 dan penerimaan pajak dari kegiatan pemeriksaan serta wawancara dengan pemeriksa pajak. Teknik analisis data menggunakan model Miles and Huberman. Hasilnya menunjukkan beberapa temuan, pertama, proses pemeriksaan pajak seharusnya berpedoman pada Pasal 8 PMK Nomor 17/PMK.03/2013 tentang tata cara pemeriksaan. Kedua, penyebab pemeriksa pajak tidak dapat mencapai target penerimaan pajak disebabkan tidak dilakukannya tahapan pemeriksaan sesuai Pasal 8 PMK Nomor 17/PMK.03/2013 dan Wajib Pajak tidak melunasi SKP yang diterbitkan oleh pemeriksa. Dengan demikian, perlu dilakukan upaya agar proses pemeriksaan sesuai Pasal 8 PMK No. 17/PMK.03/2013.
\end{abstract}

Kata kunci: Penerimaan Pajak, Pemeriksa Pajak, Wajib Pajak

\section{Abstract}

This research aimed to evaluate the causes of tax auditor's unability to accomplish the tax revenue plan from audit activities as well as the alternative solutions that could be done for optimizing tax revenue from audit activities in the future. This research used descriptive qualitative approach. Types of data collected in this study were documentation data of audit activities formed as SP2 and tax revenue from audit activities as well as interviews with tax auditors. Data was analyzed using model of Miles and Huberman. The results showed some findings, first, tax audit process should had followed Article 8 of PMK No.17/PMK.03/2013 about tax audit procedures. Second, the causes of tax auditor's unability to accomplish tax revenue target caused were the ignorance of Article 8 of PMK No.17 /PMK.03/2013 and the unpayed off SKP issued by the tax auditor which should had been done by the tax payer. Therefore, efforts should be made in order to adopt Article 8 of PMK No.17/ PMK.03 /2013 into audit process.

Keywords: Tax Revenue, Tax Inspector, Taxpayer

\section{PENDAHULUAN}

Negara Indonesia pada saat ini termasuk negara yang tingkat pertumbuhan ekonominya cukup tinggi [1]. Untuk menjaga pertumbuhan ekonomi yang cukup tinggi diperlukan pendapatan dalam negeri yang bersifat mandiri artinya bukan berasal dari utang atau hibah luar negeri. Selanjutnya dalam RAPBN 2015 dijelaskan bahwa pendapatan dalam negeri dapat berupa penerimaan negara bukan pajak sebesar Rp 388 triliun dan penerimaan perpajakan sebesar $\mathrm{Rp}$ $1.370,8$ triliun. Dalam rangka mengumpulkan penerimaan perpajakan ini, pemerintah khususnya Menteri Keuangan memberikan kewenangan kepada Direktorat Jenderal Pajak

Alamat Korespondensi Penulis:

Mohammad Yamin

Email : mohyamin12@gmail.com

Alamat : Kompleks Araya Business Center Kav 1, Jl. Raden Panji Suroso Malang 65126
(DJP) dan Direktorat Jenderal Bea dan Cukai (DJBC) untuk pelaksanaannya.

Target penerimaan perpajakan yang dibebankan kepada DJP dalam APBN selama tiga tahun anggaran terakhir (2011-2013) tidak dapat tercapai. Hal ini dapat dilihat dari perbandingan target yang tercantum dalam APBN Perubahan 2011-2013 dengan realisasinya yang terdapat dalam Laporan Keuangan Pemerintah Pusat (LKPP). Pada tahun anggaran 2011, realisasi penerimaan mencapai $99 \%$ dari target penerimaan perpajakan sebesar 878,6 triliun, tahun anggaran 2012, realisasi penerimaan mencapai $96 \%$ dari target penerimaan perpajakan sebesar 1.016,2 triliun, sedangkan untuk tahun anggaran 2013, realisasi penerimaannya hanya mencapai $94 \%$ dari target penerimaan perpajakan sebesar $1.148,3$ triliun. Kondisi ini tentunya perlu dilakukan penelitian lebih lanjut mengingat target yang terus 
meningkat tersebut tidak diikuti dengan pencapaiannya

DJP dalam rangka mengumpulkan penerimaan pajak dilakukan melalui unit pelayanannya yang tersebar di seluruh Indonesia yang disebut Kantor Pelayanan Pajak (KPP). KPP dalam rangka mengumpulkan penerimaan pajak melakukan beberapa fungsi yaitu pengawasan, pemeriksaan, dan penagihan. Fungsi pengawasan dilakukan seorang Account Representative (AR), dan fungsi pemeriksaan dilakukan oleh tim pemeriksa, sedangkan fungsi penagihan dilakukan oleh jurusita.

Penerimaan pajak merupakan hasil dari berbagai aktivitas yang dilakukan oleh fungsi pengawasan, pemeriksaan dan penagihan pada suatu KPP. Setiap fungsi ini memiliki rencana penerimaan pajak yang berbeda-beda. Untuk rencana penerimaan pajak dari fungsi pemeriksaan di setiap KPP mengikuti potensi wilayah yang dibawahinya dan cenderung meningkat setiap tahunnya seiring meningkatnya target penerimaan pajak secara nasional. Kondisi ini tidak diikuti dengan pencapaian target penerimaan tersebut. Hal ini didasarkan pada data Aplikasi Laporan Pemeriksaan Pajak (ALPP) yang terdapat pada masing-masing KPP dan secara nasional dapat dilihat dari realisasi penerimaan pajak dalam LKPP.

Target penerimaan pajak atas kegiatan pemeriksaan pada setiap KPP yang pada tahun sebelumnya tidak tercapai, maka target penerimaan atas kegiatan pemeriksaan pada tahun berikutnya akan mengalami penurunan. Kondisi ini terjadi pada KPP Madya Malang. Realisasi penerimaan pajak atas kegiatan pemeriksaan pada tahun 2012 hanya sebesar $15,09 \%$ dibandingkan rencana penerimaan sebesar 63.299.822.467. Hal ini mengakibatkan rencana penerimaan atas kegiatan pemeriksaan pada tahun 2013 menurun menjadi 36.422.450.806,-. Dengan tidak tercapainya target penerimaan pajak atas kegiatan pemeriksaan pada KPP Madya Malang merupakan obyek penelitian yang menarik bagi peneliti. Selain itu, KPP Madya Malang adalah tempat peneliti bekerja, sehingga memudahkan peneliti dalam memperoleh data dalam penelitian nantinya. Berdasarkan uraian tersebut di atas, peneliti tertarik untuk meneliti tentang pencapaian target penerimaan pajak atas kegiatan pemeriksaan (Studi pada Kantor Pelayanan Pajak Madya Malang).

\section{Penerimaan Pajak}

Pajak adalah kontribusi wajib kepada negara yang terutang oleh orang pribadi atau badan yang bersifat memaksa berdasarkan UndangUndang, dengan tidak mendapatkan imbalan secara langsung dan digunakan untuk keperluan negara bagi sebesar-besarnya kemamakmuran rakyat [2].

Penerimaan perpajakan adalah semua penerimaan negara yang terdiri atas pendapatan pajak dalam negeri dan pendapatan pajak perdagangan international [3]. Selanjutnya dijelaskan bahwa pendapatan pajak dalam negeri adalah semua penerimaan negara yang berasal dari pendapatan pajak penghasilan, pendapatan pajak pertambahan nilai barang dan jasa dan pendapatan pajak penjualan atas barang mewah, pendapatan pajak bumi dan bangunan, pendapatan cukai dan pendapatan pajak lainnya. Pendapatan pajak perdagangan international adalah semua penerimaan Negara yang berasal dari pendapatan bea masuk dan pendapatan bea keluar.

\section{Pemeriksaan Pajak}

Pemeriksaan pajak adalah sebagai serangkaian kegiatan menghimpun dan mengolah data, keterangan dan/atau bukti yang dilaksanakan secara objektif dan profesional berdasarkan suatu standar pemeriksaan untuk menguji kepatuhan pemenuhan kewajiban perpajakan dan/atau untuk tujuan lain dalam rangka melaksanakan ketentuan peraturan perundang-undangan perpajakan [4].

Kriteria pemeriksaan untuk menguji kepatuhan pemenuhan kewajiban perpajakan adalah sebagai berikut [4] :

a. Wajib Pajak menyampaikan Surat Pemberitahuan yang menyatakan lebih bayar;

b. Wajib Pajak yang telah diberikan pengembalian pendahuluan kelebihan pembayaran pajak;

c. Wajib Pajak menyampaikan Surat Pemberitahuan yang menyatakan rugi;

d. Wajib Pajak melakukan penggabungan, peleburan, pemekaran, likuidasi, pembubaran, atau akan meninggalkan Indonesia untuk selama-lamanya;

e. Wajib Pajak melakukan perubahan tahun buku atau metode pembukuan atau karena dilakukannya penilaian kembali aset tetap;

f. Wajib Pajak tidak menyampaikan atau menyampaikan Surat Pemberitahuan (SPT) tetapi melampaui jangka waktu yang telah 
ditetapkan dalam surat teguran yang terpilih untuk dilakukan pemeriksaan berdasarkan analisis risiko; atau Wajib Pajak menyampaikan Surat Pemberitahuan yang terpilih untuk dilakukan pemeriksaan berdasarkan analisis risiko.

Pemeriksaan pajak untuk menguji kepatuhan pemenuhan kewajiban perpajakan dilakukan dengan memperhatikan standar pemeriksaan. Standar pemeriksaan terdiri atas standar umum pemeriksaan, standar pelaksanaan pemeriksaan dan standar pelaporan hasil pemeriksaan [4].

Standar umum pemeriksaan berkaitan dengan persyaratan pemeriksa pajak. Pemeriksaan harus dilakukan oleh Pemeriksa pajak yang telah memenuhi syarat sebagai berikut [4] :

a. Pemeriksa telah mendapat pendidikan dan pelatihan teknis yang cukup serta memiliki keterampilan sebagai pemeriksa pajak;

b. Pemeriksa menggunakan keterampilannya secara cermat dan seksama;

c. Pemeriksa jujur dan bersih dari tindakantindakan tercela serta senantiasa mengutamakan kepentingan Negara; dan

d. Pemeriksa taat terhadap berbagai ketentuan peraturan perundang-undangan di bidang perpajakan.

Pelaksanaan pemeriksaan untuk menguji kepatuhan pemenuhan kewajiban pemeriksaan dilakukan sesuai standar pelaksanaan pemeriksaan, yaitu [4] :

a. Pelaksanaan pemeriksaan harus didahului dengan persiapan yang baik sesuai dengan tujuan pemeriksaan, yang paling sedikit meliputi kegiatan mengumpulkan dan mempelajari data Wajib Pajak, menyusun rencana pemeriksaan (audit plan), dan menyusun program pemeriksaan (audit program), serta mendapat pengawasan yang seksama;

b. Pemeriksaan dilakukan dengan melakukan pengujian berdasarkan metode dan tehnik pemeriksaan sesuai dengan program pemeriksaan (audit program) yang telah disusun;

c. Temuan hasil pemeriksaan harus didasarkan pada bukti yang kompeten yang cukup dan berdasarkan ketentuan peraturan perundang-undangan perpajakan;

d. Pemeriksaan dilakukan oleh suatu tim pemeriksa pajak yang terdiri dari seorang supervisor, seorang ketua tim, dan seorang atau lebih anggota tim dan dalam keadaan tertentu ketua tim dapat merangkap sebagai anggota tim.

e. Tim pemeriksa pajak dapat dibantu oleh seorang atau lebih yang memiliki keahlian tertentu, yang berasal dari DJP, maupun yang berasal dari instansi diluar DJP yang telah ditunjuk DJP sebagai tenaga ahli, seperti penerjemah bahasa, ahli dibidang teknologi informasi, dan pengacara;

f. Apabila diperlukan, pemeriksaan untuk menguji pemenuhan kewajiban perpajakan dapat dilakukan secara bersama-sama dengan tim pemeriksa dari instansi lain;

g. Pemeriksaan dapat dilaksanakan di kantor DJP, tempat tinggal atau tempat kedudukan Wajib Pajak, tempat kegiatan usaha atau pekerjaan bebas Wajib Pajak, dan/atau tempat lain yang dianggap perlu oleh pemeriksa pajak;

h. Pemeriksaan dilakukan pada jam kerja dan apabila diperlukan dapat dilanjutkan diluar jam kerja, dan;

i. Pelaksanaan pemeriksaan didokumentasi kan dalam bentuk Kertas Kerja Pemeriksaan (KKP).

\section{METODE PENELITIAN}

Penelitian ini menggunakan pendekatan kualitatif. Penggunaan penelitian deskriptif dengan pendekatan kualitatif ini dipandang peneliti lebih sesuai dengan fokus penelitian atas penyebab tidak tercapainya target penerimaan pajak atas kegiatan pemeriksaan. Data yang diperoleh dalam penelitian nantinya diharapkan dapat mencari solusi, agar ke depannya rencana penerimaan pajak dari kegiatan pemeriksaan dapat tercapai.

Fokus pada penelitian ini adalah mengetahui proses pemeriksaan yang seharusnya dalam mencapai target penerimaan pajak atas kegiatan pemeriksaan di KPP Madya Malang. Selanjutnya mengevaluasi penyebab tidak tercapainya target penerimaan pajak atas kegiatan pemeriksaan, serta mencari alternatif solusi langkah-langkah dan upaya sistematis yang dapat dilakukan dalam mencapai target penerimaan pajak di masa yang akan datang.

Informan dalam penelitian ini adalah pemeriksa pajak. Pemeriksa pajak pada pada KPP Madya Malang terdiri dari 5 (lima) kelompok pemeriksa dan setiap kelompok pemeriksa terdapat 3 (tiga) atau 4 (empat) tim pemeriksa pajak. Tim pemeriksa pajak terdiri dari 2 (dua) pemeriksa pajak yang terdiri dari ketua tim dan 
anggota tim sehingga total pemeriksa pajak adalah 37 pemeriksa pajak.

Analisis data pada saat melakukan penelititian kualitatif dimulai sejak sebelum berada di lapangan, selama berada di lapangan, dan setelah dari lapangan. Model analisis data di lapangan seperti Miles and Huberman [5] mengemukakan bahwa kegiatan dalam analisis data dengan pendekatan kualitatif dilakukan secara saling aktif dan berlangsung berkelanjutan sampai tuntas, sehingga nantinya data yang didapatkan sudah jenuh.

\section{HASIL DAN PEMBAHASAN}

Proses Pemeriksaan Pajak agar dapat mencapai target penerimaan pajak atas kegiatan pemeriksaan.

Pada tahap persiapan, pemeriksa mengumpulkan dan mempelajari data Wajib Pajak data keuangan, data perpajakan, laporan audit dan proses bisnis, serta analisis resiko yang dibuat oleh AR. Tetapi, pemeriksa belum seluruhnya menyusun rencana dan program pemeriksaan sesuai dengan Pasal 8 PMK Nomor 17/PMK.03/2013 [4]. Berdasarkan kondisi ini, penyusunan program dan rencana pemeriksaan mempengaruhi tahapan berikutnya yaitu penggunaan metode dan teknik pemeriksaan seperti pengujian keterkaitan antara saldo laporan rugi laba dan neraca, serta ekualisasi peredaran usaha di Surat Pemberitahuan (SPT) PPh Badan dengan Dasar Pengenaan Pajak (DPP) di SPT PPN sesuai dengan SE-65/PJ/2013 tanggal 31 Desember 2013 [6].

Pada tahap pelaksanaan pemeriksaan, sebagian pemeriksa menggunakan metode dan teknik yang tepat, efisien dan efektif sesuai dengan program pemeriksaan yang telah disusun. Tetapi atas sebagian pemeriksa yang belum menyusun program pemeriksaan tentunya tidak dapat menggunakan metode dan teknik yang tepat sehingga hal ini tidak sesuai dengan Pasal 8 PMK Nomor 17/PMK.03/2013 [4].

Pada tahap pelaporan hasil pemeriksaan, pemeriksa belum seluruhnya mendasarkan temuan hasil pemeriksaan pada bukti dan ketentuan peraturan perundang-undangan perpajakan. Hal ini tentunya tidak sesuai dengan Pasal 8 PMK Nomor 17/PMK.03/2013 [4]. Hal ini dapat disebabkan tidak disusunnya program pemeriksaan sehingga penggunaan metode dan teknik pemeriksaan yang tepat tidak dilakukan. Selanjutnya, temuan hasil pemeriksaan tidak didasarkan pada bukti dan peraturan perpajakan.
Kondisi ini akan mengakibatkan target penerimaan atas kegiatan pemeriksaan tidak tercapai, karena Wajib Pajak tidak setuju atas temuan tersebut, sehingga tidak melunasi SKP. Hal ini dibuktikan dengan hasil penelitian Siahaan [7] bahwa jumlah berkas perkara banding yang diterima oleh Pengadilan Pajak pada tahun 2011 telah meningkat sebesar $680 \%$ sejak tahun 2002. Selain itu, jumlah sengketa banding yang dimenangkan oleh Wajib Pajak untuk periode 2008 s.d 2010 lebih besar dibandingkan oleh pemeriksa pajak.

\section{Penyebab Pemeriksa Pajak tidak dapat mencapai target penerimaan pajak atas kegiatan pemeriksaan}

Penyebab pemeriksa pajak tidak dapat mencapai target penerimaan pajak atas kegiatan pemeriksaan dibedakan menjadi 2 (dua) yaitu :

1) Penyebab secara internal yaitu proses pemeriksaan yang tidak sesuai Pasal 8 PMK Nomor 17/PMK.03/2013, seperti pemeriksa tidak melaksanakan tahap persiapan pemeriksaan dengan baik, pemeriksa tidak menggunakan metode dan teknik pemeriksaan, khususnya pengujian tidak langsung serta pemeriksa tidak dapat menunjukkan bukti dan dasar peraturan perpajakan atas temuan hasil pemeriksaan.

2) Penyebab eksternal, dengan rincian sebagai berikut :

a. Target penerimaan dari kegiatan pemeriksaan seharusnya bukan target utama karena bertentangan dengan Pasal 2 PMK Nomor 17/PMK.03/2013, pemeriksaan bertujuan untuk menguji pemenuhan kewajiban perpajakan bukan untuk penerimaan perpajakan. Maksudnya kegiatan pemeriksaan ditujukan untuk menguji kewajiban perpajakan Wajib Pajak yang dilaksanakan sesuai peraturan perundang-undangan perpajakan atau tidak. Apabila Wajib Pajak tidak melaksanakan kewajiban perpajakannya dengan baik, maka secara otomatis akan mengakibatkan timbulnya SKP yang harus dibayar oleh Wajib Pajak, sehingga penerimaan pajak merupakan efek samping dari dilakukannya pemeriksaan, sedangkan yang utama adalah untuk menguji kepatuhan pemenuhan kewajiban perpajakan. 
b. Adanya analisis resiko pemeriksaan yang dibuat oleh AR sebagai dasar penerbitan SP2 pemeriksaan khusus tidak otomatis dapat diselesaikan dalam bentuk temuan hasil pemeriksaan. Hal ini disebabkan analisis resiko pemeriksaan tidak didasarkan pada bukti atau data pihak ketiga dan peraturan perpajakan yang berlaku. Kondisi ini dapat diketahui dari perbandingan temuan hasil pemeriksaan dengan analisis resiko pemeriksaan yang dibuat oleh AR atas Wajib Pajak tersebut.

c. Jumlah SP2 yang terbit terlalu banyak. Hal ini sesuai dengan tabel 1, pada tahun 2011 hanya sebesar 208 SP2, sedangkan tahun 2014 menjadi sebesar 319. Apabila di rata-rata dengan jumlah pemeriksa yang sebesar 30 pemeriksa maka setiap pemeriksa harus menyelesaikan 7 LHP pada tahun 2011 dan 10 LHP pada tahun 2014, sehingga untuk mencapai jumlah LHP tersebut pemeriksa harus menyelesaikan 1 LHP maksimal 1,5 bulan. Dengan adanya kondisi ini, maka jangka waktu penyelesaian pemeriksaan terlalu sempit. Hal ini dapat dibandingkan dengan Pasal 15 PMK Nomor 17/PMK.03/2013, jangka waktu pemeriksaan paling lama 6 (enam) bulan.

Tabel 1 SP2 yang diterbitkan dan diselesaikan Tahun 2011-2014 (dalam kasus)

\begin{tabular}{|c|c|r|r|r|r|}
\hline No & Tahun & SP2 Terbit & SP2 Selessai & $\begin{array}{c}\text { Jumlah } \\
\text { Pemeriksa }\end{array}$ & $\begin{array}{c}\text { Beban SP2 per } \\
\text { pemeriksa }\end{array}$ \\
\hline 1 & 2 & 3 & 4 & 5 & $6=3: 5$ \\
\hline 1 & 2011 & 208 & 217 & 30 & 6.9 \\
2 & 2012 & 254 & 202 & 30 & 8.4 \\
3 & 2013 & 435 & 318 & 30 & 14.5 \\
4 & 2014 & 319 & 408 & 30 & 10.6 \\
\hline
\end{tabular}

Sumber : ALPP KPP Madya Malang

d. Jumlah SP2 terbit sebagian besar merupakan pemeriksaan rutin lebih bayar. Hal ini sesuai dengan tabel 2, pada tahun 2011 jumlah konversi penyelesaian SP2 (LHP) pemeriksaan rutin sebesar 126,2 dan pemeriksaan khusus 8,5. Tahun 2014 pemeriksaan rutin sebesar 159,5 dan pemeriksaan khusus 68,1 . Dengan lebih banyaknya pemeriksaan rutin, maka temuan hasil pemeriksaan harus lebih baik agar t mengubah status SPT Wajib Pajak yang sebelumnya lebih bayar atau rugi tidak lebih bayar sebelum diperiksa menjadi kurang bayar setelah diperiksa, sehingga rencana penerimaan pajak dari kegiatan pemeriksaan dapat dicapai. Hal ini tentunya akan mengakibatkan beban kerja pemeriksa menjadi lebih berat.

\begin{tabular}{|c|c|r|r|r|r|}
\hline $\mathrm{d}$ & \multicolumn{1}{|c|}{$\begin{array}{c}\text { Pemsus (semua } \\
\text { jenis pajak) }\end{array}$} & Total \\
\hline 1 & 2 & 3 & 5 & 6 \\
\hline 1 & 2011 & 58,2 & 4 & 5,5 & 134,7 \\
2 & 2012 & 57,3 & 68,0 & 3,7 & 119,0 \\
3 & 2013 & 74,3 & 58,0 & 64,5 & 213,8 \\
4 & 2014 & 20,7 & 75,0 & 68,1 & 227,7 \\
\hline
\end{tabular}

Sumber : ALPP KPP Madya Malang

Tabel 2 Konversi Penyelesaian SP2 (LHP) Tahun 2011-2014 
e. Wajib Pajak tidak melunasi SKP yang diterbitkan oleh pemeriksa. Hal ini disebabkan kondisi Wajib Pajak yang tidak likuid ataupun karena tingkat kesadaran Wajib Pajak masih rendah untuk membayar pajak. Hal ini sesuai dengan tabel 3, pada tahun 2011 pelunasan SKP hanya sebesar $20,12 \%$ dari jumlah $\mathrm{Rp}$ 56.687.210.028 dan pada tahun 2014 sebesar 51,35\% dari jumlah Rp 92.387.359.982.

Tabel 3 Perbandingan Jumlah SKP terbit dengan Realisasi Penerimaan Pajak atas Kegiatan Pemeriksaan Tahun 2011-2014 (dalam rupiah)

\begin{tabular}{|c|c|c|c|c|c|c|}
\hline \multirow{2}{*}{ No } & \multirow{2}{*}{ Tahun } & \multirow{2}{*}{ SKP } & \multirow{2}{*}{ Realisasi } & \multirow{2}{*}{ Defisit } & \multicolumn{2}{|c|}{$\%$} \\
\hline & & & & & Realisasi & Defisit \\
\hline 1 & 2 & 3 & 4 & 5 & 6 & 7 \\
\hline 1 & 2011 & 56.687 .210 .028 & 11.403 .136 .094 & 45.284 .073 .934 & $20,12 \%$ & $79,88 \%$ \\
\hline 2 & 2012 & 17.527 .379 .467 & 9.552 .328 .747 & 7.975.050.720 & $54,50 \%$ & $45,50 \%$ \\
\hline 3 & 2013 & 126.646.372.177 & 81.111 .384 .511 & 45.534 .987 .666 & $64,05 \%$ & $35,95 \%$ \\
\hline 4 & 2014 & 92.387 .359 .982 & 47.440 .855 .670 & 44.946.504.312 & $51,35 \%$ & $48,65 \%$ \\
\hline \multicolumn{2}{|c|}{ Total } & 200.860 .961 .672 & 149.507 .705 .022 & 51.353 .256 .650 & $74,43 \%$ & $25,57 \%$ \\
\hline
\end{tabular}

Sumber : ALPP KPP Madya Malang

\section{Upaya Pemeriksa Pajak agar dapat mencapai rencana penerimaan Pajak}

Pada tahap persiapan pemeriksaan yang harus diperbaiki adalah belum dipelajarinya data Wajib Pajak baik laporan keuangan maupun proses bisnis, sehingga rencana dan program pemeriksaan tidak disusun dengan baik. Selain itu, berdasarkan wawancara secara lisan dari beberapa informan ternyata rencana dan program pemeriksaan tidak seluruhnya dibuat, karena kewajiban membuat hal itu terletak pada supervisor atau ketua kelompok, sehingga pemeriksa malu atau tidak mau untuk menegur atasannya, agar dibuatkan rencana dan program pemeriksaan. Dengan adanya kondisi ini, maka perlu adanya pengawasan melekat dari Kepala Kantor atas penyusunan program pemeriksaan.

Pada tahap pelaksanaan pemeriksaan yang perlu diperbaiki adalah metode dan teknik pemeriksaan yang harus dilakukan oleh pemeriksa sesuai dengan program pemeriksaan yang telah dibuat, seperti melakukan pengujian persediaan di lokasi usaha Wajib Pajak pada saat pemeriksaan di lapangan.

Pada tahap pelaporan hasil pemeriksaan yang perlu dilakukan pemeriksa adalah meningkatkan kemampuan negotiation skill dan communication skill dengan Wajib Pajak terutama dalam permintaan data, bukti dan dokumen yang mendukung temuan hasil pemeriksaan. Selain itu, kemampuan pemeriksa dalam menggunakan metode dan teknik serta peraturan perundangundangan perpajakan perlu terus ditingkatkan agar mampu memperoleh temuan hasil pemeriksaan yang baik.

Target penerimaan pajak atas kegiatan pemeriksaan untuk tahun 2014 sebesar Rp 126.797.300.000,- seharusnya didasarkan pada potensi KPP Madya Malang tepatnya potensi setiap Wajib Pajak yang nantinya akan diperiksa, bukan berdasarkan prosentase tertentu dari kenaikan APBN tahun sebelumnya. Dengan demikian, permasalahan dapat terukur dan diketahui penyebab tidak tercapainya target penerimaan dari kegiatan pemeriksaan.

Berkomunikasi dengan AR dalam rangka analisis resiko pemeriksaan yang lebih baik agar nantinya dapat diperoleh temuan hasil pemeriksaan yang baik. Hal ini diperkuat oleh fakta pada tabel 4 bahwa realisasi penerimaan pajak dari pemeriksaan khusus pada tahun 2011 sebesar Rp 730.232.448 dan pada tahun 2014 menjadi sebesar Rp 39.203.838.718. Oleh karena itu, perlu ditingkatkan jumlah dan kualitas analisis resiko pemeriksaan yang dibuat oleh AR sehingga realisasi penerimaan dari kegiatan pemeriksaan khsusus terus meningkat. 
Tabel 4 Pencapaian Target Penerimaan Pajak Berdasarkan Jenis Pemeriksaan Tahun 2011-2014 (dalam rupiah)

\begin{tabular}{|c|c|r|r|r|r|r|}
\hline No & Tahun & Pemeriksaan Rutin & $\begin{array}{c}\text { Pemeriksaan } \\
\text { Khusus }\end{array}$ & \multicolumn{2}{|c|}{ Total } & \multicolumn{2}{|c|}{ Pemtin } & Pemsus \\
\hline 1 & 2 & 3 & 4 & 5 & $6=3: 5$ & $7=4: 5$ \\
\hline 1 & 2011 & 10.672 .903 .646 & 730.232 .448 & 11.403 .136 .094 & $93,60 \%$ & $6,40 \%$ \\
2 & 2012 & 8.128 .076 .304 & 1.424 .252 .443 & 9.552 .328 .747 & $85,09 \%$ & $14,91 \%$ \\
3 & 2013 & 70.135 .944 .036 & 10.975 .440 .475 & 81.111 .384 .511 & $86,47 \%$ & $13,53 \%$ \\
4 & 2014 & 8.237 .016 .952 & 39.203 .838 .718 & 47.440 .855 .670 & $17,36 \%$ & $82,64 \%$ \\
\hline \multicolumn{2}{|c|}{ Total } & 97.173 .940 .938 & 52.333 .764 .084 & 149.507 .705 .022 & $65,00 \%$ & $35,00 \%$ \\
\hline
\end{tabular}

Sumber : ALPP KPP Madya Malang

Perlu dilakukan penambahan jumlah Wajib Pajak yang diperiksa sehingga potensi Wajib Pajak yang belum diperiksa dapat tergali dengan baik. Hal ini perlu dilakukan karena Wajib Pajak yang sering diperiksa biasanya telah memperbaiki kesalahan berdasarkan temuan hasil pemeriksaan tahun-tahun sebelumnya pada saat diperiksa.

Membuat sistem penghargaan dan sanksi yang jelas apabila pemeriksa tidak dapat memenuhi rencana penerimaan dari kegiatan pemeriksaan. Hal ini perlu dilakukan, karena DJP merupakan aparatur negara dengan status pegawai negeri sipil (PNS). Peraturan tentang disiplin PNS diatur dalam Pasal 9 butir 12 Peraturan Pemerintah Nomor 53 Tahun 2010 yang menyatakan bahwa hukuman disiplin sedang dijatuhkan apabila pencapaian sasaran kerja pada akhir tahun hanya mencapai $25 \%$ sampai dengan 50\% [8]. Adanya kondisi tidak tercapainya penerimaan dari kegiatan pemeriksaan tahun 2014 yang hanya sebesar $37,41 \%$ sesuai tabel 5 , seharusnya dikenakan hukuman disiplin sedang tetapi faktanya tidak terdapat hukuman tersebut. Hal ini disebabkan pencapaian rencana penerimaan dari kegiatan pemeriksaan merupakan salah satu unsur penilaian kinerja pemeriksa. Hal ini sesuai dengan Pasal 15 Peraturan Pemerintah Nomor 46 Tahun 2011 bahwa bobot penilaian prestasi kerja atas sasaran kinerja pegawai sebesar $60 \%$ dan perilaku $40 \%$ [9].

Tabel 5 Realisasi Penerimaan Pajak atas Kegiatan Pemeriksaan Tahun 2011-2014 (dalam rupiah)

\begin{tabular}{|c|c|c|c|c|c|c|}
\hline \multirow{2}{*}{ No } & \multirow{2}{*}{ Tahun } & \multirow{2}{*}{ Rencana } & \multirow{2}{*}{ Realisasi } & \multirow{2}{*}{ Defisit } & \multicolumn{2}{|l|}{$\%$} \\
\hline & & & & & Realisasi & Defisit \\
\hline 1 & 2 & 3 & 4 & 5 & 6 & 7 \\
\hline 1 & 2011 & 74.520 .054 .700 & 11.403 .136 .094 & 63.116 .918 .606 & $15,30 \%$ & $84,70 \%$ \\
\hline 2 & 2012 & 63.299 .822467 & 9.552 .328 .747 & 53.747 .493 .720 & $15,09 \%$ & $84,91 \%$ \\
\hline 3 & 2013 & 36.422 .450 .806 & 81.111.384.511 & (44.688.933.705) & $222,70 \%$ & $0 \%$ \\
\hline 4 & 2014 & 126.797 .300 .000 & 47.440 .855 .670 & 79.356 .444 .330 & $37,41 \%$ & $62,59 \%$ \\
\hline \multicolumn{2}{|c|}{ Total } & 301.039 .627 .973 & 149.507 .705 .022 & 151.531 .922 .951 & $49,66 \%$ & $50,34 \%$ \\
\hline
\end{tabular}

Sumber : ALPP KPP Madya Malang

\section{KESIMPULAN}

Proses pemeriksaan pajak seharusnya berpedoman pada Pasal 8 PMK Nomor 17/PMK.03/2013 tentang tata cara pemeriksaan. Pelaksanaan setiap tahapan pemeriksaan saling mempengaruhi keberhasilan pemeriksaan.

Penyebab pemeriksa pajak tidak dapat mencapai target penerimaan pajak dibedakan menjadi 2 (dua) yaitu, pertama secara internal karena tidak sesuai dengan tahapan pemeriksaan dalam Pasal 8 PMK Nomor 17/PMK.03/2013, kedua, secara eksternal seperti pencapaian rencana penerimaan pajak dari kegiatan pemeriksaan seharusnya bukan target utama, analisis resiko pemeriksaan yang dibuat oleh $A R$ sebagai dasar penerbitan SP2 pemeriksaan khusus tidak otomatis dapat diselesaikan dalam bentuk temuan hasil pemeriksaan serta Wajib Pajak tidak melunasi SKP yang diterbitkan oleh pemeriksa 
Upaya pemeriksa agar rencana penerimaan dapat tercapai dilakukan dengan berkomunikasi dengan $A R$ dalam rangka analisis resiko pemeriksaan yang lebih baik agar nantinya dapat diperoleh temuan hasil pemeriksaan yang baik, menamb jumlah Wajib Pajak yang diperiksa sehingga potensi Wajib Pajak yang belum diperiksa dapat tergali dengan baik serta membuat sistem penghargaan dan sanksi yang jelas apabila pemeriksa tidak dapat memenuhi rencana penerimaan

\section{SARAN}

1. Bagi Pemeriksa Pajak KPP Madya Malang, perlu adanya keberanian tim pemeriksa untuk memberitahukan kepada supervisor atau ketua kelompok agar menyusun rencana dan program pemeriksaan sebagai dasar dilakukannya pemeriksaan oleh tim pemeriksa sehingga pemeriksaan lebih efektif dan efisien. Selain itu, perlu adanya komunikasi yang berkelanjutan dengan $A R$ terutama dalam pemilihan Wajib Pajak yang akan dilakukan analisis resiko pemeriksaan yang nantinya dijadikan dasar usulan pemeriksaan khusus sehingga potensi pajaknya dapat tergali dengan baik.

2. Bagi Kepala Kantor KPP Madya Malang, perlu adanya pengawasan yang berkelanjutan dari Kepala Kantor agar hambatan dalam pelaksanaan pemeriksaan oleh kelompok fungsional pemeriksa dapat diberikan solusi agar pencapaian rencana penerimaan dari kegiatan pemeriksaan dapat maksimal. Selain itu, perlu adanya analisa resiko pemeriksaan dari AR dengan potensi minimal mendekati jumlah rencana penerimaan dari kegiatan pemeriksaan sehingga rencana penerimaan dari kegiatan pemeriksaan dapat dilaksanakan dengan lebih baik.

\section{UCAPAN TERIMA KASIH}

Penulis menyampaikan ucapan terima kasih kepada :

1. Seluruh jajaran civitas akademi pada Jurusan Magister Akuntansi Fakultas Ekonomi dan Bisnis atas ilmu yang telah diberikan serta pelayanan yang diberikan sehingga penelitian ini dapat berjalan dengan baik.

2. Pegawai KPP Madya Malang khususnya teman-teman fungsional pemeriksa pajak yang telah memberikan data dan informasi penelitian.

3. Istriku dan anak-anakku tercinta yang telah mendukungku menyelesaikan penelitian ini.

\section{DAFTAR PUSTAKA}

[1]. Kementerian Keuangan. 2015. Nota Keuangan dan Rancangan Anggaran Pendapatan dan Belanja Negara (RAPBN). Jakarta

[2]. Undang-Undang Nomor 16 Tahun 2007 tentang Perubahan Ketiga atas UndangUndang Nomor 6 tahun 1983 tentang Ketentuan Umum dan Tata Cara Perpajakan (KUP)

[3]. Undang-Undang Nomor 23 Tahun 2013 Tentang Anggaran Pendapatan dan Belanja Negara Tahun Anggaran 2014

[4]. Peraturan Menteri Keuangan Nomor 17/PMK.03/2013 tentang Pemeriksaan Pajak

[5]. Sugiyono. 2014. Metode Penelitian Kuantitatif Kualitatif dan R\&D, Bandung : ALFABETA

[6]. Surat Edaran Direktur Jenderal Pajak No. 65/PJ/2013 tentang Pedoman Penggunaan Metode dan Teknik Pemeriksaan. Direktorat Jenderal Pajak. Jakarta

[7]. Siahaan, Rony R.P, 2012, Kajian Penyebab Permohonan Banding Wajib Pajak Dimenangkan di Pengadilan Pajak dan Upaya-Upaya DJP untuk Meminimalisirnya, Tesis, Program Administrasi dan Kebijakan Perpajakan, Program Pascasarjana Fakultas IImu Sosial dan IImu Politik Universitas Indonesia

[8]. Peraturan Pemerintah Nomor 53 Tahun 2010 tentang disiplin Pegawai Negeri Sipil

[9]. Peraturan Pemerintah Nomor 46 Tahun 2011 tentang Penilaian Prestasi Kerja Pegawai Negeri Sipil 